\title{
Analysis the Pattern of the Implementation of Distance Learning in Increasing Competence of Human Resources Apparatus in Semarang Religious Education and Training Center
}

\author{
Nikmatul Afiyah ${ }^{1}$, Sundarso ${ }^{2}$, Hardi Warsono ${ }^{3}$, Tri Yuniningsih ${ }^{4}$ \\ $\left\{\right.$ hardie_wsn@yahoo.com ${ }^{3}$ \} \\ Universitas Diponegoro, Indonesia ${ }^{1,2,3,4}$
}

\begin{abstract}
This study is about the pattern of the implementation of distance learning in Semarang Religious Education and Training Center. The objective to be achieved is to analyze the pattern of distance learning (DJJ) implementation so that distance learning can become an alternative training program that can improve the competency of Human Resources Apparatus in the Ministry of Religious Affairs. This study is descriptiveanalytical with qualitative methods. The results of the study are as follows: First, distance learning of Semarang Religious Training Center in 2019 has been carried out using the full online method, without any face to face, separate between participants and lecturer (widyaiswara) which are brought together through information and communication technology; Secondly, the pattern of the implementation of distance learning using the full online method has produced good outputs and received good feedback from participants. Recommendations that can be given are: Firstly, it needs effort and development of distance learning implementation in a sustainable manner related to the recruitment of participants, learning methods, and forms of evaluation due to technological demands that are constantly evolving; secondly, need to improve the quality of human resources implementing education, especially lecturers in the operationalization of the distance learning implementation; thirdly, need to improve infrastructure to support the quality of distance learning implementation.
\end{abstract}

Keywords: Distance Learning (DJJ), Competence, Human Resources

\section{Introduction}

State Civil Apparatus (ASN) competency development within the Ministry of Religion is carried out by the Education and Training Center located at the center and the Education and Training Centers in the regions. The Ministry of Religion, which has around 250,000 employees with 2 (two) Education and Training Centers and 14 (fourteen) Training Centers throughout Indonesia, has not been able to fulfill the demands of the education and training needs maximally (Head of Administrative Personnel Training Center). This will be a problem when the ratio between the numbers of human resources in the apparatus reaches thousands and the number of training held is not balanced so that the opportunity to get increased competence takes a long time.

The Semarang Religious Education and Training Center is one of the technical implementation units of the Ministry of Religion in the regions that oversees 2 (two) regions, 
namely the Province of Central Java and the Special Region of Yogyakarta with a total of 49,018 employees. There are 164 training programs in 2019, where one batch accommodates approximately 35 people so that with such a capacity, employees only have the opportunity to train 8.5 every year. Moreover, when non-PNS employees also have to get training opportunities, the number of opportunities to attend training (training rates) at Semarang Religious Education and Training Center is still very low.

Seeing the phenomenon that occurred and seeing the limited number of education programs at Semarang Religious Education and Training Center in 2019, of course, it is necessary to think about how to develop the type of education and training. Training programs at Semarang Religious Education and Training Center that have been implemented so far are Regular Education and Training, Training in Work Areas (DDWK), Cooperation Training (MoU), and Distance Training (DJJ).

Distance Training is an alternative education and training offered and implemented by the Semarang Religious Education and Training Center and is expected to accommodate the needs of employees for training. The implementation of distance learning in 2019 received a good reception from employees, this was evidenced by the enthusiasm of the participants who registered and exceeded the quota provided so that participant selection was carried out. This condition occurs because distance learning is an alternative education and training for employees who do not have the opportunity to take part in the programmed training.

The distance learning in Semarang Religious Education and Training Center uses the full online method. The use of the full online method in implementing distance learning is certainly not perfect as expected, especially since 2019 is the beginning of implementing distance learning with the full online method. Obstacles and obstacles will certainly color at the beginning of the distance learning implementation at Semarang Religious Education and Training Center. This is what encourages the author to analyze and study further about the pattern of distance learning implementation so that a pattern is found that is easily accepted, implemented and of course following the needs of employees. The implementation pattern in question can be started from the recruitment of participants, the delivery of technical materials from the lecturers, the form of assignments, even evaluation, all of which are aimed at improving the competence of human resources.

Based on the background of the above problems, the questions in this study are: "How to analyze the pattern of conducting distance training at the Semarang Religious Education and Training Center in increasing the competence of human resources apparatus".

The purpose of this study was to analyze the pattern of conducting distance training at the Semarang Religious Education and Training Center in improving the competence of human resources.

The results of this study are expected to be useful for contributing to agencies in the pattern of providing distance training following the needs to increase the competence of human resources in providing public services.

\section{Literature Review}

\subsection{Distance Learning}

Permendikbud No. 109 of 2013 [1], article 1 paragraph 1 states that distance education is a teaching and learning process carried out remotely through the use of various 
communication media. Previously in Law no. 12 of 2012 on Higher Education in the seventh part of Distance Education mentions the same thing. It is stated in the Law that distance education is aimed: a) to provide higher education services to community groups who cannot attend face-to-face or regular education, b) expand access and facilitate higher education services in education and learning.

Meanwhile, in State Administration Agency (LAN) Regulation No. 8 of 2018 [2] concerning Guidelines for Implementing Competency Development for Civil Servants through e-learning, it is stated that e-learning is the development of civil servant competencies carried out in the form of training by optimizing the use of information and communication technology to achieve learning objectives and performance improvements. In the implementation of e-learning, it is aimed at a) increasing the efficiency and effectiveness of the implementation of competency development, b) expanding access for civil servants in developing competencies on an ongoing basis, and c) accelerating the improvement of organizational performance.

\subsection{Implementation of Policies in Education and Training}

Grindle [3] states that implementing a policy depends on the content and context, and the success rate depends on the condition of the 3 components of the required implementation resource variables. These three components cause the national program to produce variations in outputs and outcomes that are different in regions.

\subsection{Competency Improvement Strategy}

Mustopadidjaja [4] states that Apparatus HR competence generally means the capabilities and characteristics of a civil servant in the form of knowledge, skills, attitudes, and behaviors needed in carrying out their duties. According to Suyuti (2010) states that to improve the competence of human resources, there is a need for a strategy because adequate competence is something that needs to be understood and implemented by all levels of government apparatus both at central and regional levels. According to Sedarmayanti [5], strategies to improve the competence of human resources for apparatus need to be carried out continuously so that it will produce productive human resources. Efforts that must be made in increasing the competence of human resources include: a) Increasing competence which includes technical competence, conceptual competence, and competence to live in dependence, b) Organizations that continue to learn, c) Developing creativity and innovation, d) Utilizing intellectual capital as the organization's new wealth.

Government Regulation No. 11 of 2017 article 203 states that competency development is an effort to meet the competency needs of civil servants with job competency standards and career development plans. Competency development can be carried out at the institutional and national levels in the form of education and / or training. Competency development in the form of education is carried out to increase the knowledge and skills of civil servants through formal education. Meanwhile, competency development in the form of training is carried out through classical and non-classical training channels. Competency development in the form of classical training is carried out through a face-to-face learning process in the classroom, at least through training, seminars, courses, and upgrades. Competency development in the form of non-classical training is carried out at least through e-learning, workplace guidance, distance training, internships, and exchanges between civil servants and private employees. 


\subsection{Previous Research}

There are lots of studies that discuss improving the quality of apparatus resources, of which the results are in improving the provision of services to the public because one of the functions of ASN in the ASN Law is as a public servant. Megalia [6] states that increasing the competence of apparatus resources can be done through education and training programs.

As for research related to distance training, it can be seen, among others, the writing of Diningrat [7] which publishes online learning design as an effort to facilitate learning in the workplace. This paper has produced an integrated learning design framework in online learning this framework is an alternative model that educators and learning designers can use in designing and developing effective online learning models. This model not only pays attention to socio-cultural factors that are usually not predicted by online learning designs, but this model also provides a comprehensive description of the tasks of educators and learning designers in online learning. The model in this learning has an exploration, design, and evaluation stage that can realize online learning according to the needs of students. With the existence of an integrated learning design framework, independent learning activities will be more structured.

Barak [8] in his writings which identifies and describes the organizational and cultural changes that occur when distance education is implemented in a higher education institution in Israel. Several faculties support the implementation of distance education, but some also expressed a negative attitude by assuming that there would be a waste of resources (time, energy, and money). In this study, it is hoped that institutions/organizations can improve learning for their resources so that they can contribute to the improvement and development of professional human resources.

Another discussion in the world of education was written by Jui [9] who explained that NOU (National Open University) in increasing the development of teaching media learning needs to change teaching policies and learning styles to adapt to the challenges of distance education in Taiwan. That step can be done by developing distance education technology, adjusting the number of TV programs, increasing learning channels. What makes distance learning seem new is the development and wide availability of new technologies for connecting learners and instructors, the rate at which this technology has been adopted by educational, government, and commercial organizations, and the wide publicity.

Another study that discusses distance education is D'Agustino which conducted a research survey on effective design models for online learning to identify best practices in presenting new models recommends an eight-step process that occurs in three phases. The first stage, the identification stage, encourages the instructor and/or course design team to identify strategies, objectives, assessments, and resources. In the second stage, design, instructors select, organize, adapt, and reflect. The last stage is implementation, where training is taught. However, this study states that there is no single model or design that appears as superior or the most effective and efficient, so the model offered is a combination of models that thesis the most aspects of the existing models.

\section{Methodology}

This research is descriptive-analytical, which seeks to describe and analyze the pattern of conducting distance training as a strategy to increase the competence of Human Resources 
(HR) Apparatus in the work area of the Semarang Religious Education and Training Center. This study using qualitative research methods, as a research procedure that produces descriptive data in the form of written or spoken words from people and observable behavior.

The informants in this study were: a) structural officers of Semarang Religious Education and Training Center, b) functional officers of trainer (widyaiswara) Semarang Religious Education and Training Center, c) General Functional Positions (JFU) Semarang Religious Education and Training Center, d) Alumni of education and training.

Data collection techniques in this study using observation and interview techniques. The observation technique is carried out by making direct observations in the field of the object under study so that an accurate interpretation of the data can be obtained while interviews were conducted by free interviews.

There are two types of data used in this study, namely:

a. Primary data, namely data obtained from respondents in this study, where the researcher obtained these data from parties related to the process of implementing the education and training either by observation or direct interviews.

b. Secondary data, namely data obtained by collecting materials from books and regulations related to the problem under study.

The research data was collected from the results of literature studies and field studies which came from observations and interviews with respondents, the analysis was carried out in the following stages:

a. Data collection, data is collected relating to the problem under study

b. Data checking, the data that has been collected is checked whether it is as expected or not

c. Data organizing, namely grouping the data that has been collected so that it can answer researchers' questions

d. Interpreting the data, this is done to extract the meaning contained in the data

e. Discuss and formulate the results of interpretations that have been sorted to answer the researcher's questions

f. Draw the conclusion.

\section{Results and Discussion}

Based on the results of observations and distribution of questionnaires to organizers and implementers of education and training (structural officials, General Functional Positions (JFU), trainer (widyaiswara), and training participants) it can be seen that the Distance.

Training which has been held at the Semarang Religious Education and Training Center is one of the methods of organizing education and training that has opportunities for easy access and equal distribution of training opportunities for employees of the Ministry of Religion, especially in the working areas of Central Java and Yogyakarta Provinces.

Distance training is non-classical training carried out in the context of developing the competence of Civil Servants aimed at increasing the expansion and equity in training. This is following what is stated in PP 17 of 2010 concerning the Management and Implementation of Education which in distance education has characteristics that are following the demands of the current era, namely open, independent learning, thorough learning, using educational information and communication technology, and/or use other educational technology.

The application of technology in Distance Training at the Semarang Religious Education and Training Center using video conferencing, WhatsApp is very helpful in the learning process even though technical obstacles are unavoidable. However, this becomes a challenge 
and an evaluation for improving the implementation of distance learning (DJJ) in Semarang Religious Education and Training Center.

Considering that distance learning has become a demand as one of the models for implementing education so that it requires cooperation from all internal and external stakeholders. Based on the research data, it can be seen that the organizers and implementers of education and training already know and understand about distance learning. Stakeholders' knowledge and understanding of Distance Training becomes the capital in the successful implementation of distance learning. The implementation of distance learning is carried out remotely, namely using a learning model that is between participants and separate resource persons, emphasizing the principles of independent, structured, and guided learning by using various learning sources. Learning media is a learning resource that is more dominant in learning because of the interaction of learning based on information and communication technology even though it allows limited face-to-face learning. Semarang Religious Education and Training Center has implemented distance learning using a fully online system.

The results of the analysis of why Semarang Religious Education and Training Center implemented distance learning were based on realistic conditions which were the answers to educational problems such as the training cycle that was too long due to a large number of employees with a limited number of training activities. distance learning as diversification of education and training activities is considered capable of providing solutions to the education and training cycle so that the greater the opportunity for employees to be able to get competency development. This is in line with Sedarmayanti's [5] opinion that competency development needs to be carried out continuously so that it will produce productive human resources.

Distance training is also able to increase budget efficiency and be able to increase the number of alumni. The greater number of alumni that can be generated from distance learning makes it easier for the implementation of its implementation policies. The theory of implementation from Grindle [3] states that the content of policies that can influence implementation is one of the benefits generated. Policies that provide collective benefits or too many people are easier to implement because they are easier to get support from target groups or communities. Distance learning which was held at Semarang Religious Education and Training Center has received positive responses from users (employees of the Ministry of Religion of Central Java and DIY). This was evidenced by the enthusiasm of the participants to register for distance learning which was quite significant even at certain training sessions that exceeded the quota so that participant selection was necessary. Participants have also felt the benefits of distance learning, in which the understanding and skills of information technology have certainly increased, apart from of course the material content which is the purpose of learning.

The implementation of distance learning at Semarang Religious Education and Training Center has added color to the implementation of the discipline which is a demand in today's digital era. The pattern of implementation using video conferencing, providing a special room for chatting, and the existence of assignments that have to be completed by participants in each course of the training so far can run well, safely under control. A more stable server will be very helpful during learning because it can produce good quality in video conferencing.

2019 is the beginning of the distance learning implementation with the full online method at Semarang Religious Education and Training Center so that the scheduling is still not well organized as well as the committee and the budget. This is part of several issues that need to be evaluated so that future distance learning implementation can be even better. Infrastructure and Human Resources have been quite good so far, this can be seen from the 
implementation of 8 (eight) distance learning that has been realized from the 10 (ten) distance learning planned in 2019. There are 2 (two) distance learning which are programs of the Administrative Personnel Section that have not been implemented because it coincided with Latsar CPNS Group III activities which were so busy until the end of the fiscal year. The use of the full online method can be carried out in a controlled manner, it's just that the final result of training in the form of a certificate cannot be printed online by the participant (ecertificate). This is a concern for the implementation of distance learning in 2020 because it is fully online based so that e-certificates can be applied.

The pattern of organizing distance learning which is carried out with one training course per week plus the existence of assignments is quite good in covering the training material, it is hoped that participants will understand the material content as evidenced by the completion of the given assignments. The chat room is intended for a deeper discussion about the material content so that when someone doesn't understand it, they can be discussed in the forum.

Evaluation and monitoring of the implementation of distance learning are always needed, both pre-evaluations, during activities, and post-activity evaluations. The existence of continuous evaluation is intended to improve the quality of the distance learning Semarang Religious Education and Training Center. All of that needs support from all related parties, organizers, implementers, and users because in the future distance learning has become a routine training program at BDK Semarang to improve the competence of Human Resources Apparatus at the Ministry of Religion.

\section{Conclusion}

The 2019 Semarang Religious Education and Training Center have been carried out with a full online method, without face-to-face, separate participants and lecturers who are brought together through information and communication technology. The use of video conferencing, the availability of space for chatting, assignments in learning are learning media to transfer knowledge so that participants understand the training material being followed.

The implementation of the Distance Education and Training Center for the Semarang Religious Education and Training Center is the answer to the challenges of the digital era as well as to shorten the training cycle for the Ministry of Religion employees, especially in Central Java and Yogyakarta Province. The design of the DJJ implementation pattern using the full online method has produced good output and received good feedback from participants. In the future, DJJ is expected to be able to make breakthroughs in increasing the quantity of education and training alumni and the quality of HR competencies of the Ministry of Religion.

\section{Recommendation}

a. Efforts and development are needed in the implementation of DJJ in a sustainable manner related to participant recruitment, learning methods, and forms of evaluation due to the ever-evolving demands of technology.

b. It is necessary to improve the quality of human resources who carry out the training, especially lecturers in the operation of the DJJ.

c. It is necessary to improve infrastructure to support the quality of DJJ implementation. 


\section{References}

[1] Permendikbud, Permendikbud RI No. 109 of 2013 concerning the Implementation of Distance Education in Higher Education. 2013.

[2] LAN, "Copy of Regulation of the Republic of Indonesia's State Administration Agency No. 8 of 2018 concerning Guidelines for Implementing Competency Development for Civil Servants through e-Learning."

[3] M. S. Grindle, Politics and policy implementation in the Third World, vol. 4880. Princeton University Press, 1980.

[4] Mustopadidjaja, Development Paradigms. 2002.

[5] Sedarmayanti, Human Resource Management, Bureaucratic Reform, and Civil Service Management. Jakarta: Refika Aditama, Graha Ilmu, 2011.

[6] R. Megalia, "Management of Apparatus Implementation Improvement: A Study on the Implementation of Human Resources Reform Policy in the Education and Training Agency in Indonesia," Mindamas.com Journals., 2011.

[7] S. W. Diningrat, "Design of Online Learning Models as Efforts to Facilitate Learning in the," 2019.

[8] M. Barak, "Distance education: towards an organizational and cultural change in higher education," J. Enterprising Communities People Places Glob. Econ., 2012.

[9] H. M. Jui, "A Challenge for open and distance education in Taiwan.," Asian Open Univ. J., 2006. 